\title{
Assessment of the impact of Intrauterine Growth Restriction on Gastrointestinal Tract Tolerance to Nutrition in Very Low Birth Weight Neonates at Zagazig University Hospital
}

Abdel Razek Mohamed El sheikh, Atef Mohamed Mohamed Khalil, Rabab Reyad Abdallah*

Department of Pediatric, Faculty of Medicine - Zagazig University, Egypt

*Corresponding author: Rabab Reyad Abdallah, Mobile: (+20) 01141289126, Email: rabab_reyad@yahoo.com

\begin{abstract}
Introduction: Very low birth weight (VLBW) is a term used to describe babies who are born weighing less than1.5 kilograms. The main cause of a baby having VLBW is being born too early and this is called preterm or premature birth. Premature means a baby is born before 37 weeks of pregnancy. Another cause of very low birth weight is when a baby does not grow well during pregnancy and this is called intrauterine growth restriction (IUGR), it may happen because of problems with the placenta, the mother's health, or birth defects.

Objective: This study aimed to assess the impact of intrauterine growth restriction on gastrointestinal tract tolerance to nutrition in very low birth weight neonates. Patients and Methods: This study was applied on 48 very low birth weight neonates who were divided into two equal groups (AGA and SGA groups). They were admitted to NICU in Zagazig University Children Hospital, during the period from March 2020 to September 2020.

Results: Incidence rate of feeding intolerance was nearly equal in SGA and AGA very low birth weight neonates, but incidence of feeding intolerance signs were different between them. Conclusion: Intra-uterine growth restricted Very low birth weight newborns were susceptible to intrauterine deprivation of nutrients to gastrointestinal tract due to placental insufficiency resulting in prematurity and immaturity of gastrointestinal tract function resulting in poor tolerability of GIT to enteral feeding. Trophic feeding, which was early initiation of enteral feeding along with parenteral nutrition seemed to improve feeding tolerance, decrease duration of parenteral nutrition, insure more mature intestinal motility patterns and increase growth rate.
\end{abstract}

Keywords: Intrauterine growth restriction, Gastrointestinal tract tolerance, Nutrition.

\section{INTRODUCTION}

Very low birth weight (VLBW) is a term used to describe babies who are born weighing less than 1.5 kilograms. The main cause of a baby having VLBW is being born too early and this is called preterm or premature birth. Premature means a baby is born before 37 weeks of pregnancy. VLBW babies are often born before 30 weeks of pregnancy. A premature baby has less time in the mother's uterus to grow and gain weight. Much of baby's weight is gained during the latter part of pregnancy ${ }^{(\mathbf{1})}$. Another cause of VLBW is when a baby does not grow well during pregnancy and this is called intrauterine growth restriction (IUGR), which may happen because of problems with the placenta, the mother's health, or birth defects. Most VLBW babies who have IUGR are also born early and they are usually very small and physically immature. IUGR is associated with medical conditions that interfere with circulation and efficiency of placenta with the development or growth of the fetus, these medical conditions are maternal hypertension and placental separation ${ }^{(2)}$.

A condition of placental dysfunction lead to cardiovascular adaptation in the fetus characterized by redistribution of cardiac output to maintain oxygen supply to the heart, adrenal glands and brain, the so called brain sparing effect at the expense of visceral organs such as gastrointestinal tract. This condition may predispose to IUGR infants to impaired gut function after birth. A higher incidence of necrotizing enterocolitis is documented in IUGR and preterm infants. So, a common practice in neonatal intensive care unit is to delay feeds to reduce the risk of feeding intolerance but recent trials have shown that early enteral feeding in IUGR infants is safe ${ }^{(3)}$.

Parenteral nutrition is essential for VLBW (premature or IUGR) to provide sufficient fluids, calories, amino acid, electrolytes and vitamins to sustain the growth of ill neonate but long-term parenteral nutrition and no receiving enteral nutrition can cause cholestatic jaundice and liver disease ${ }^{(4)}$.

The parenteral nutrition component should contain $2.5-3.5 \mathrm{~g} / \mathrm{dl}$ of synthetic amino acids and usually 10 - $15 \mathrm{~g} / \mathrm{dl}$ of glucose, in addition to appropriate quantities of electrolytes, trace minerals and vitamins. Intravenous fat emulsion such as intra-lipid 20\% maybe administrated to provide calories initiated at $2 \mathrm{~g} / \mathrm{kg} / 24$ hours within 24 hours after birth and increased to 3 $\mathrm{g} / \mathrm{kg} / 24$ hours by the next day ${ }^{(5)}$.

When neonate is clinically stable, we start trophic feeding. Trophic feeding is practice of feeding very small amounts of enteral nourishment to VLBW neonate $(10-20 \mathrm{ml} / \mathrm{kg} / 24$ hours as a continuous nasogastric tube drip or by intermittent gavage every 2-3 hours for 5-10 days) to enhance gut motility, improve growth, and decrease need for parenteral nutrition. If initial feedings are tolerated, the volume is increased by $20-30 \mathrm{ml} / \mathrm{kg} / 24$ hours till a volume of $150 \mathrm{ml} / \mathrm{kg} / 24$ hours has been achieved ${ }^{(4)}$. 
Vomiting, regurgitation, abdominal distension or gastric residuals from previous feedings are evidences of feeding intolerance, these conditions are indications to stop feedings at least temporarily, and to increase subsequent feedings slowly only as tolerated or to change to intra- venous alimentation. Gastric residuals mean all or substantial part of previous feeding that must be aspirated by naso gastric tube, and it is advisable to withhold feedings or to reduce the amount of feeding and proceed more gradually with subsequent increase depending on physical finding and other evidence of feeding intolerance ${ }^{(6)}$.

The aim of this work was to study the impact of intrauterine growth restriction on GIT tolerance to nutrition among very low birth weight neonates.

\section{PATIENTS AND METHODS}

This prospective cohort study included 48 cases of preterm VLBW neonates admitted to NICU in Zagazig University Hospital, during the period from March 2020 to September 2020, in order to know feeding intolerance in VLBW newborns and the effect of IUGR on it. Our neonates were divided into two groups (SGA) group and (AGA) group.

N.B: SGA group contains (24) preterm VLBW neonates with birth weight less than $10^{\text {th }}$ percentile for that particular gestational age while AGA group contains (24) preterm VLBW neonates with birth weight between $10^{\text {th }}$ and $90^{\text {th }}$ percentile as per the gestational age $^{(7)}$.

\section{Ethical consideration:}

The study was approved by the Ethical Committee of Zagazig Faculty of Medicine. An informed consents were obtained from all patients' parents. Every patient' parent received an explanation for the purpose of the study. All given data were used for the current medical research only. This work has been carried out in accordance with The Code of Ethics of the World Medical Association (Declaration of Helsinki) for studies involving humans.

Inclusion Criteria: Preterm neonates with birth weight equal or less than $1500 \mathrm{~g}$. Both males and females were included. Also, neonates who were delivered by either cesarean section or normal vaginal delivery.

Exclusion Criteria: Congenital anomalies (for example congenital heart and congenital gastrointestinal tract anomalies), suspected sepsis, transfer from another hospital, any cases of liver or other organs impairment, and if parents refused to participate in the study.

\section{All patients were subjected to the following:}

1) Full clinically history taking: Prenatal history, natal history, and postnatal examination including: (a) Age, sex. (b) Anthropometric measures (weight, length, head circumference). (c) APGAR scoring at first and five minutes. (d) Feeding problems.

2) Complete clinical examination including: (a) General examination; Estimation of gestational age by Ballord score ${ }^{(8)}$, level of consciousness, color, vital signs (respiratory rate, heart rate and temperature). (b) Regional examination. (c) Systemic examination: (i) Respiratory examination (respiratory rate, signs of respiratory distress and apnea including down score). (ii) Neurological examination (neonatal reflexes, tone and level of consciousness). (iii) Cardiovascular (pulse \& heart rate). (iv) Abdominal examination (Abdominal distention, hepatomegaly, splenomegaly, ascites, dilated veins and rash).

Apgar scoring system was assigned at 1 and 5 minutes after birth as a method of evaluation of the newborn infant as follow ${ }^{(9)}$ :

\begin{tabular}{|c|c|c|}
\hline $\begin{array}{l}\text { core } \\
\text { ign }\end{array}$ & 0 & 2 \\
\hline eart rate & Absent & $\begin{array}{l}\text { Less than } 100 \text { More than } \\
\text { bpm }\end{array}$ \\
\hline $\begin{array}{l}\text { esp } \\
\text { for }\end{array}$ & & Slow (irregular)Good crying \\
\hline Iuscle tone & eLimp & $\begin{array}{l}\text { Some flexion of Act } \\
\text { extremities mo }\end{array}$ \\
\hline eflex & $\begin{array}{l}\text { No } \\
\text { response }\end{array}$ & Grimace \\
\hline 1 & $\begin{array}{l}\text { Blue, } \\
\text { Pale }\end{array}$ & $\begin{array}{l}\text { ink body, blueAll pin } \\
\text { xtremities }\end{array}$ \\
\hline
\end{tabular}

(v) Infant breathes spontaneously, heart rate is more than $100 \mathrm{bpm}$ and color is judged to be becoming pink, Apgar score is 8 to 10 . (vi) Infant breathes spontaneously, heart rate is more than $100 \mathrm{bpm}$ but the overall color appears cyanotic, Apgar score is 5 to 7. (vii) The infant is apneic despite tactile stimulation or has a heart rate of less than $100 \mathrm{bpm}$ despite apparent respiratory effort, Apgar score is 3 to 4 . (viii) The infant is apneic and the heart rate is less than $100 \mathrm{bpm}$ despite 30 seconds of assisted ventilation, Apgar score is 0 to 2 .

3) Nutritional sheet:

It includes parenteral nutrition phase, trophic feeding phase, and enteral nutrition phase.

(a) Parenteral nutrition (PN) phase sheet included the number of infants on both groups on parenteral nutrition (\%), age of infants when PN was started (days), duration of PN (days), maximum protein intake in $\mathrm{PN}(\mathrm{gm} / \mathrm{kg} /$ day), maximum lipid intake within PN $(\mathrm{gm} / \mathrm{kg} /$ day) and total calories in PN (kcal/day).

(b) Trophic feeding phase sheet included the percentage of infants in two group reaching to this phase (\%), ages of infants when this phase was started (days), duration of this phase (days), volume of milk (ml/day) and total calories in this phase (kcal/day).

(c) Full enteral nutrition phase sheet included the percentage of infants reaching to this phase (\%), ages of infants in this phase (days), duration of this phase (days), volume of milk (ml/day) and total calories in this phase (kcal/day). 
(d) Then we included feeding intolerance as a complication of enteral feeding in our two groups of very low birth weight neonates involving feeding intolerance signs (gastric residuals, abdominal distention, emesis and constipation or diarrhea) and feeding intolerance incidence percentage between two groups of our very low birth weight newborns (SGA / AGA ).

\section{Statistical Analysis:}

All data were collected, tabulated and statistically analyzed using IBM SPSS Statistics for Windows, Version 23.0 (Armonk, NY: IBM Corp). Quantitative data were expressed as mean \pm SD \& range, and qualitative data were expressed as percentage. t-test was used to compare between two groups of normally distributed variables. Mann Whitney $U$ test was used to compare between two groups of non-normally distributed variables. Repeated measure ANOVA test was used to compare between more than two variables of normally distributed variable, and least significant difference was used to detect significance between groups. While, Freidman test was used to compare between more than two dependent groups of nonnormally distributed variables. Percent of categorical variables were compared using Chi-square test or Fisher eact test when appropriate. All tests were two sided. Pvalue $\leq 0.05$ was considered statistically significant $(\mathrm{S})$, and $\mathrm{p}$-value $>0.05$ was considered statistically insignificant (NS).

\section{RESULTS}

There was statistically insignificant difference between SGA and AGA neonates regarding mode of delivery and Apgar score at first minute and five minute after labor ( $\mathrm{p}>0.05)$ as shown in table (1).
Table (2) showed that there was statistically insignificant difference between SGA and AGA neonates regarding manifestation of feeding intolerance $(\mathrm{p}>0.05)$.

There was statistically significant difference between SGA and AGA neonates regarding PN parameters. It was observed that mean of PN maximum lipid intake by AGA neonates was markedly higher than SGA neonates $(\mathrm{p}=0.025)$. Also mean total caloric intake via $\mathrm{PN}$ route was more among AGA $(124.37 \pm 16.42)$ compared to SGA neonates (91.43 \pm 42.73s); the difference statistically significant $(\mathrm{p}=0.001)$ Table (3).

Table (4) showed that there was statistically significant difference between SGA and AGA neonates regarding trophic feeding phase parameters. It was observed that mean milk volume per day in trophic feeding phase was more among AGA (55.67 \pm 43.91$)$ compared to SGA neonates $(33.44 \pm 29.37)$ and the difference was statistically significant $(\mathrm{p}=0.007)$. Total caloric intake among AGA neonates was higher than SGA neonates in this phase so the difference was statistically significant $(\mathrm{p}=0.0001)$.

There was statistically insignificant difference between SGA and AGA neonates regarding full enteral feeding parameters $(\mathrm{p}>0.05)$ (Table 5).

Table (6) showed that incidence of food intolerance sign was $95.8 \%$ among SGA group compared to $100 \%$ of AGA group. The difference was statistically insignificant $(\mathrm{p}>0.05)$, but there was statistically significant difference between AGA and SGA neonates regarding some feeding intolerance signs ( $\mathrm{p}$ value $=0.01)$. One sign was gastric residual volume (GRV) more than $30 \%$ of previous feeding, vomiting, abdominal distention, constipation. While two signs were combination of GRV and vomiting or abdominal distention and vomiting or GRV and abdominal distention (Table 6).

Table (1): Demographic data among the studied groups

\begin{tabular}{|c|c|c|c|c|c|c|}
\hline \multirow{2}{*}{ Variables } & \multicolumn{4}{|c|}{ Studied groups } & \multirow[t]{2}{*}{$\chi^{2}$} & \multirow{2}{*}{$\begin{array}{c}\text { p- } \\
\text { value }\end{array}$} \\
\hline & \multicolumn{2}{|c|}{ SGA $n=24$} & \multicolumn{2}{|c|}{ AGA $n=24$} & & \\
\hline $\begin{array}{l}\text { Gestational age (weeks) } \\
\text { - Mean } \pm \mathrm{SD} \\
\text { - } \text { Median(range) }\end{array}$ & \multicolumn{2}{|c|}{$\begin{array}{c}33 \pm 2.9 \\
33.5(22-36)\end{array}$} & \multicolumn{2}{|c|}{$\begin{array}{l}32.42 \pm 1.84 \\
32(30-35)\end{array}$} & $\mathrm{t}=0.892$ & 0.38 \\
\hline Mode of delivery & No. & $\%$ & No. & $\%$ & & \\
\hline - Normal & 10 & 41.67 & 13 & 54.17 & 0.75 & 0.38 \\
\hline - $\mathrm{CS}$ & 14 & 58.33 & 11 & 45.83 & & \\
\hline \multicolumn{7}{|l|}{ Sex } \\
\hline - Female & 14 & 58.33 & 15 & 62.50 & 0.087 & 0.77 \\
\hline - Male & 10 & 41.67 & 9 & 37.50 & & \\
\hline APGAR score at first minute & \multicolumn{2}{|c|}{$\cdot$} & & & \\
\hline $\begin{array}{ll}\text { - } & \text { Mean } \pm \text { SD } \\
\text { - } & \text { Median (range) } \\
\end{array}$ & \multicolumn{2}{|c|}{$\begin{array}{c}5.6 \pm 1.5 \\
5(4-7) \\
\end{array}$} & \multicolumn{2}{|c|}{$\begin{array}{c}6.3 \pm 2.1 \\
6(5-8)\end{array}$} & $\mathrm{t}=1.3$ & 0.19 \\
\hline $\begin{array}{l}\text { APGAR score at five minute } \\
\text { - Mean } \pm \text { SD } \\
\text { - Median (range) } \\
\end{array}$ & \multicolumn{2}{|c|}{$\begin{array}{c}6.2 \pm 1.7 \\
6(4-8)\end{array}$} & \multicolumn{2}{|c|}{$\begin{array}{l}7.1 \pm 2.3 \\
7(5-8) \\
\end{array}$} & $\mathrm{t}=1.54$ & 0.13 \\
\hline
\end{tabular}

$\chi^{2}$ Chi square test $\mathrm{t}$ student $\mathrm{t}$ test of significant $\mathrm{p}>0.05=$ non-significant 
Table (2): Signs of feeding intolerance between our studied groups

\begin{tabular}{|c|c|c|c|c|c|c|}
\hline \multirow{3}{*}{ Variables } & \multicolumn{4}{|c|}{ Studied groups } & \multirow{3}{*}{$\chi^{2}$} & \multirow{3}{*}{ p-value } \\
\hline & \multicolumn{2}{|c|}{ SGA $n=24$} & \multicolumn{2}{|c|}{ AGA n=24 } & & \\
\hline & No. & $\%$ & No. & $\%$ & & \\
\hline \multicolumn{7}{|l|}{ Vomiting } \\
\hline - Present & 10 & 41.67 & 4 & 16.67 & 3.6 & 0.057 \\
\hline - absent & 14 & 58.33 & 20 & 83.33 & & \\
\hline \multicolumn{7}{|c|}{ Gastric residual (volume>30\%) } \\
\hline - Present & 13 & 54.17 & 11 & 45.83 & 0.33 & 0.56 \\
\hline - absent & 11 & 45.83 & 13 & 54.17 & & \\
\hline \multicolumn{7}{|c|}{ Abdominal distension } \\
\hline - Present & 10 & 41.67 & 13 & 54.17 & 0.75 & 0.38 \\
\hline - absent & 14 & 58.33 & 11 & 45.83 & & \\
\hline \multicolumn{7}{|c|}{ Constipation (no stool $>24$ hours) } \\
\hline - Present & 2 & 8.33 & 0 & .00 & $\mathrm{f}$ & 0.49 \\
\hline - absent & 22 & 91.67 & 24 & 100.00 & & \\
\hline
\end{tabular}

Table (3): Parenteral nutrition ( $\mathrm{PN}$ ) parameters among our studied groups

\begin{tabular}{|c|c|c|c|c|}
\hline \multirow{2}{*}{ Items of PN } & \multicolumn{2}{|c|}{ Studied groups } & \multirow{2}{*}{ t-test } & \multirow[b]{2}{*}{$\mathbf{p}$} \\
\hline & $\mathrm{SGA} n=24$ & AGA $n=24$ & & \\
\hline $\begin{array}{l}\text { PN No }(\%) \\
\text { - Yes } \\
\text { - No }\end{array}$ & $\begin{array}{l}17(70.8 \%) \\
7(29.2 \%)\end{array}$ & $\begin{array}{c}19(79.2) \\
5(20.8 \%)\end{array}$ & $\begin{array}{l}\chi^{2}= \\
0.44\end{array}$ & 0.50 \\
\hline $\begin{array}{l}\text { Age of neonates when PN is started } \\
\text { (days) } \\
\text { - Mean } \pm \text { SD } \\
\text { - Median (range) }\end{array}$ & $\begin{array}{c}2.4 \pm 2.6 \\
1(0.00-8)\end{array}$ & $\begin{array}{c}5.21 \pm 5.11 \\
4(1-14)\end{array}$ & 1.83 & 0.067 \\
\hline $\begin{array}{l}\text { PN duration } \\
\text { - Mean } \pm \text { SD } \\
\text { - Median (range) }\end{array}$ & $\begin{array}{l}3.53 \pm 3.04 \\
2(0.00-12)\end{array}$ & $\begin{array}{c}3.79 \pm 1.18 \\
4(2-5)\end{array}$ & 1.4 & 0.159 \\
\hline $\begin{array}{l}\text { Maximum of protein intake } \\
\text { (gm/kg/day) during PN phase } \\
\text { - Mean } \pm \text { SD } \\
\text { - Median (range) }\end{array}$ & $\begin{array}{c}3.44 \pm 0.29 \\
3.5(2.1-3.5)\end{array}$ & $\begin{array}{c}3.5 \pm 0.00 \\
3.5(3.5-3.5)\end{array}$ & 0.96 & 0.34 \\
\hline $\begin{array}{l}\text { Maximum of lipid intake } \\
\text { (gm/kg/day) during PN phase } \\
\text { - Mean } \pm \text { SD } \\
\text { - Median (range) }\end{array}$ & $\begin{array}{l}2.53 \pm 0.38 \\
2.6(1.2-3) \\
\end{array}$ & $\begin{array}{l}2.74 \pm 0.21 \\
2.8(2.4-3) \\
\end{array}$ & 2.3 & 0.025 \\
\hline $\begin{array}{l}\text { Total Caloric intake in PN phase } \\
\text { (kcal//day) } \\
\text { - Mean } \pm \text { SD } \\
\text { - Median (range) }\end{array}$ & $\begin{array}{l}91.43 \pm 42.73 \\
108(.00-125)\end{array}$ & $\begin{array}{l}124.37 \pm 16.42 \\
124(100-150)\end{array}$ & 3.19 & 0.001 \\
\hline
\end{tabular}


Table (4): Trophic feeding phase parameters among our studied groups.

\begin{tabular}{|c|c|c|c|c|}
\hline \multirow{2}{*}{ Trophic feeding phase items } & \multicolumn{2}{|c|}{$\begin{array}{c}\text { Transitional phase for very low } \\
\text { birth weight }\end{array}$} & \multirow{2}{*}{ MW } & \multirow{2}{*}{$\mathbf{p}$} \\
\hline & $\mathrm{SAG} \leq 1500 \mathrm{n}=24$ & AGA $n=24$ & & \\
\hline $\begin{array}{l}\text { Number of neonate on trophic feeding } \\
\text { phase } n(\%) \\
\text { - Yes } \\
-\quad \text { no }\end{array}$ & $\begin{array}{l}24(100 \%) \\
0.0\end{array}$ & $\begin{array}{l}24(100 \%) \\
0.0\end{array}$ & $\mathrm{f}$ & - \\
\hline $\begin{array}{l}\text { Age of neonates when trophic feeding } \\
\text { phase is started (days) } \\
\text { - Mean } \pm \text { SD } \\
\text { - Median (range) }\end{array}$ & $\begin{array}{c}3.3 \pm 2.43 \\
3(1-10)\end{array}$ & $\begin{array}{l}4.83 \pm 3.49 \\
5(1-12)\end{array}$ & 1.5 & 0.133 \\
\hline $\begin{array}{l}\text { Trophic feeding phase duration } \\
\text { (days) } \\
\text { - Mean } \pm \text { SD } \\
\text { - Median (range) }\end{array}$ & $\begin{array}{l}8.57 \pm 3.91 \\
8(2-18)\end{array}$ & $\begin{array}{l}7.71 \pm 3.49 \\
8(1-13)\end{array}$ & 0.57 & 0.570 \\
\hline $\begin{array}{ll}\text { - } & \text { Milk volume }(\mathrm{ml} / 3 \mathrm{~h}) \text { in trophic } \\
\text { feeding phase } \\
\text { - } \\
\text { - Mean } \pm \mathrm{SD} \\
\text { Median } \pm \mathrm{SD}\end{array}$ & $\begin{array}{l}4.26 \pm 3.62 \\
3(2-20)\end{array}$ & $\begin{array}{l}6.99 \pm 5.49 \\
5(2-20)\end{array}$ & 2.6 & 0.009 \\
\hline $\begin{array}{l}\text { Milk volume (ml/day) in trophic } \\
\text { feeding phase } \\
\text { - } \quad \text { Mean } \pm \text { SD } \\
\text { - } \quad \text { Median (range) }\end{array}$ & $\begin{array}{l}33.44 \pm 29.37 \\
24(9-160)\end{array}$ & $\begin{array}{l}55.67 \pm 43.91 \\
40(16-160)\end{array}$ & 2.68 & 0.007 \\
\hline $\begin{array}{l}\text { Total caloric intake during trophic } \\
\text { feeding phase (kcal/day) } \\
\text { - Mean } \pm \text { SD } \\
\text { - Median (range) }\end{array}$ & $\begin{array}{l}193.78 \pm 50.88 \\
212(97-280)\end{array}$ & $\begin{array}{l}250.33 \pm 16.89 \\
254(222-280)\end{array}$ & 5.16 & 0.0001 \\
\hline
\end{tabular}

Table (5): Full enteral feeding parameters among our studied groups.

\begin{tabular}{|c|c|c|c|c|}
\hline \multirow{2}{*}{ Items of full enteral feeding } & \multicolumn{2}{|c|}{$\begin{array}{c}\text { Full enteral feeding for very low birth } \\
\text { weight }\end{array}$} & \multirow[b]{2}{*}{ t-test } & \multirow{2}{*}{$\mathbf{p}$} \\
\hline & SGA N=24 & AGA N=24 & & \\
\hline $\begin{array}{l}\text { Full enteral feeding (\%) } \\
\text { - Yes } \\
\text { - No }\end{array}$ & $\begin{array}{l}15(62.5 \%) \\
9(37.5 \%)\end{array}$ & $\begin{array}{l}19(79.2 \%) \\
5(20.8 \%)\end{array}$ & $\begin{array}{l}\chi^{2}= \\
1.61\end{array}$ & 0.204 \\
\hline $\begin{array}{l}\text { Age of neonates when full enteral } \\
\text { feeding is started (days) } \\
\text { - Mean } \pm \mathrm{SD} \\
\text { - Median (range) }\end{array}$ & $\begin{array}{c}12.07 \pm 4.98 \\
11(6-23)\end{array}$ & $\begin{array}{c}10.89 \pm 5.12 \\
13(2-16)\end{array}$ & 0.105 & $0.92 *$ \\
\hline $\begin{array}{l}\text { Milk volume (ml/day) in full enteral } \\
\text { feeding } \\
\text { - } \quad \text { Mean } \pm \mathrm{SD} \\
\text { - Median (range) }\end{array}$ & $\begin{array}{l}197.5 \pm 55.56 \\
200(.00-240)\end{array}$ & $\begin{array}{l}206.32 \pm 14.99 \\
200(200-240)\end{array}$ & 0.66 & .0 .51 \\
\hline $\begin{array}{l}\text { Total caloric intake from enteral } \\
\text { feeding(kcal/day) } \\
\text { - Mean } \pm \text { SD } \\
\text { - Median (range) }\end{array}$ & $\begin{array}{l}152.94 \pm 44.67 \\
160(0.00-195)\end{array}$ & $\begin{array}{l}165.53 \pm 13.11 \\
160(160-195)\end{array}$ & 1.17 & 0.25 \\
\hline $\begin{array}{l}\text { Type formula no }(\%) \\
\text { - Pre term }(81 \mathrm{kcal} / 100 \mathrm{ml})\end{array}$ & $24(100 \%)$ & $24(100 \%)$ & $\mathrm{f}$ & - \\
\hline
\end{tabular}

*Mann Whitney u test 
Table (6): Incidence of feeding intolerance among our studied groups.

\begin{tabular}{||l|c|c|c|c|c|c||}
\hline \multirow{2}{*}{\multicolumn{1}{|c|}{ Items }} & \multicolumn{2}{|c|}{ SGA (n=24) } & \multicolumn{2}{c|}{ AGA (n=24) } & \multirow{2}{*}{$\boldsymbol{\chi}^{\mathbf{2}}$} & \multirow{2}{*}{$\mathbf{p}$} \\
\cline { 2 - 7 } & $\mathbf{N o}$ & $\mathbf{\%}$ & $\mathbf{N o}$ & $\mathbf{\%}$ & & \\
\hline Incidence of feeding intolerance & & & & & & \\
\hline Absent & 1 & 4.2 & 0 & 0 & \multirow{2}{*}{$\mathrm{f}$} & 0.99 \\
Present & 23 & 95.8 & 24 & 100 & \\
\hline Signs of feeding intolerance & 11 & 47.8 & 20 & 83.3 & 6. & \multirow{2}{*}{0.01} \\
One sign \\
Two signs & 12 & 52.2 & 4 & 16.7 & 6 & \\
\hline
\end{tabular}

$\mathrm{NS}=$ non- significant $\mathrm{p}>0.05$

\section{DISCUSSION}

There was statistically insignificant difference between SGA and AGA neonates regarding gender, mode of delivery and Apgar score at first minute and five minutes after labor $(\mathrm{p}>0.05)$. This is in agreement with the study of Baserga and Sola ${ }^{(2)}$ where there were no significant differences between the AGA and SGA groups regarding gender, racial distribution, incidence of death and age at which death occurred.

The present study showed that there was statistically insignificant difference between SGA and AGA neonates regarding manifestation of feeding intolerance $(\mathrm{p}>0.05)$. The incidence of feeding intolerance signs was $95.8 \%$ among SGA group compared to $100 \%$ of AGA group. Our results are supported by study of Ahammad $\boldsymbol{e t}$ al. ${ }^{(10)}$ as they reported that total percentage of feeding intolerance among the study population was $36.7 \%$. Feeding intolerance in group-1 and group-2 were $40.0 \%$ and $34.3 \%$ respectively. But the difference was not statistically significant. The babies were stratified on enrolment into two groups according to gestational age of 28 to 32 weeks (group-1) and > 32 to 36 weeks (group-2). Jadcherla et al. ${ }^{(11)}$ conducted a study on impact of prematurity and co-morbidities on feeding milestones in neonates. They found infants $>28$ weeks GA (i.e., group-2 and group-3) attained successful feeding milestones by similar PMA.

The current study showed that there was statistically significant difference between SGA and AGA neonates regarding TPN parameters. It was observed that mean of TPN max lipid intake by AGA neonate is higher than SGA neonate $(\mathrm{p}=0.025)$. Also mean total caloric intake via TPN route was more among AGA (124.37 \pm 16.42$)$ compared to SGA neonate $(91.43 \pm 42.73)$. The difference statistically significant $(p=0.001)$. Our results are supported by study of Späth et al. ${ }^{(12)}$ as they reported that PN was the main source of energy during postnatal days $0-5$ and supplied on average $27 \%$ of the energy intake during the second postnatal week (postnatal days 7-13). Infants in the concentrated PN group received significantly higher parenteral and total energy intakes during postnatal days $1-5$ and $1-10$, respectively, compared to infants in the original PN group. In Hu et al. ${ }^{(13)}$, the study revealed that there is significant difference between SGA VLBW group and AGA VLBW group regard time to start parenteral nutrition (age/days) but no significant difference in duration of TPN (days).

In the study in our hands, there was statistically significant difference between SGA and AGA neonates regarding trophic feeding parameters. It was observed that mean of minimum milk volume $3 \mathrm{~h}$ trophic feeding intake by AGA neonate was higher than SGA neonate $(\mathrm{p}=0.009)$. Also mean minimum milk volume day trophic feeding was more among AGA (55.67 \pm 43.91$)$ compared to SGA neonate $(33.44 \pm 29.37)$ and the difference was statistically significant $(\mathrm{p}=0.007)$. This led total caloric intake of trophic feeding in AGA neonate to be higher than SGA neonates and the difference was statistically significant (p0.0001).

Several old studies had verified the potential benefits of trophic feeding and there was no general agreement about the optimal timing to start enteral feeds (14). In Tyson and Kennedy ${ }^{(15)}$ a systematic review of Cochrane data base revealed that only time to full enteral feeding, number of days that feedings were withheld and total hospital stay were significantly reduced following trophic feeding but there is still uncertainty about the exact time of starting minimal enteral feeding. In Bomnell et al. ${ }^{(16)}$ in their review yielded that early trophic feeding did not provide any evidence to affect feeding tolerance or growth rates in VLBW infants. Considering all these results benefits and hazards of early versus delayed initiation of enteral feedings in parenterally fed preterm LBW infants have received very little study, and the effects on major clinical outcome remain uncertain. But, in Tang et al. (17) study, enteral nutrition initiation was recommended within 12 hours after birth depending on respiratory and circulatory status of an infant. Also in Ruan et al. ${ }^{(18)}$ study, it was reported that infants who are clinically stable, received minimal enteral feeding as early as possible after birth.

The present study showed that there was statistically insignificant difference between SGA and AGA neonates regarding full enteral feeding parameters (p>0.05). In the study of Corvaglia et al. ${ }^{(19)}, 1.775$ (95.2\%) achieved FEF (full enteral feeding). The median time for achieving FEF was 13 days (IQR 7-24 days) and the meantime 18.25 days $(\mathrm{SD}=17.56)$. The nine NICUs differed significantly on time to FEF achievement (ANOVA test: $F=31.11, p<0.001$ ) and on the frequency of several prenatal and postnatal 
variables. Baserga and Sola ${ }^{(2)}$ reported that regarding enteral feedings, ELBW-SGA infants reached wellsustained feeds at a significantly later age $(20.5 \pm 3.6$ vs $12.8 \pm 1.9$ days of life, $p<0.0001)$ and had a higher number of feeding intolerance episodes $(16.5 \pm 3.6 \mathrm{vs}$ $9.6 \pm 3.4$ episodes, $\mathrm{p}<0.0001)$ when compared to ELBW-AGA babies. There was no significant difference between the amount of protein and total calories received by the two groups. However, in ELBW-SGA infants, the maximum dextrose and lipid intake ever received was significantly higher when compared to ELBW-AGA infants.

There was statistically insignificant difference between SGA and AGA neonate regarding outcome after follow up period ( $p>0.05$ ). The mean time between admission for SGA and death is 16.5 days compared to 19.75 days for AGA. This is meaning that chance of survival is more for AGA neonates. But, there was no significant difference [Log Rank test p-value (0.14)].

\section{CONCLUSION}

Intra uterine growth restricted very low birth weight newborns were susceptible to intrauterine deprivation of nutrients to gastrointestinal tract due to placental insufficiency resulting in prematurity and immaturity of gastrointestinal tract function resulting in poor tolerability of GIT to enteral feeding. Trophic feeding, which was early initiation of enteral feeding along with parenteral nutrition improved feeding tolerance, decreased duration of parenteral nutrition, insured more mature intestinal motility patterns and increased growth rate.

\section{Financial support and sponsorship: Nil. Conflict of interest: Nil.}

\section{REFERENCES}

1. Liu Z, Liu G, Wu X et al. (2015): Value of early application of different doses of amino acids in parenteral nutrition among preterm infants. Zhongguo Dang Dai Er Ke Za Zhi., 17 (1): 537.

2. Baserga M, Sola A (2004): Intrauterine growth restriction impacts tolerance to total parenteral nutrition in extremely low birth weight infants. Journal of Perinatology, 24 (8): 476-481.
3. Bozzetti V, Tagliabue P, Visser G et al. (2013): Feeding issues in IUGR preterm infants. Early Hum Dev., 89: 21-3.

4. Lee S, Kim N, Namgung $R$ et al. (2018): Prediction of postnatal growth failure among very low birth weight infants. Scientific Reports, 8 (1): 3729-32.

5. Ben X (2008): Nutritional management of newborn infants: practical guidelines. World J Gastroenterol., 14 (40): 61336139.

6. Barone G, Maggio L, Saracino A et al. (2013): How to feed small for gestational age newborns. Ital J Pediatr., 10: 39:28.

7. Sharma D, Farahbakhsh N, Shastri S et al. (2016): Intrauterine growth restriction - part 2. J Matern Fetal Neonatal Med., 29 (24): 4037-48.

8. Ballard J (1999): Anticoagulant-induced thrombosis. JAMA., 282 (4): 310-2.

9. Kasdorf E, Laptook A, Azzopardi D et al. (2015): Improving infant outcome with a 10 min Apgar of 0. Arch Dis Child Fetal Neonatal Ed., 100 (2): 102-105.

10. Ahammad F, Begum T, Akter J et al. (2018): Comparison of feeding intolerance between very preterm and moderate preterm neonates - a prospective cohort study. J Pediatr Neonatal Care, 8 (4): 200-203.

11. Jadcherla S, Wang M, Vijayapal A et al. (2010): Impact of prematurity and co-morbidities on feeding milestones in neonates: a retrospective study. J Perinatol., 30 (3): 201-208.

12. Späth C, Zamir I, Sjöström S et al. (2020): Use of concentrated parenteral nutrition solutions is associated with improved nutrient intakes and postnatal growth in very lowbirth-weight infants. Journal of Parenteral and Enteral Nutrition, 44 (2): 327-336.

13. Hu F, Tang Q, Wang Y et al. (2019): Analysis of nutrition support in very low-birth-weight infants with extrauterine growth restriction. Nutr Clin Pract., 34 (3): 436-443.

14. Kliegman R, Behrman $R$, Jenson $H$ et al. (2011): Nelson Text Book of Pediatrics. 19th ed. Philadelphia: Saunders, Pp: 978-80. https://med-mu.com/wpcontent/uploads/2018/08/Nelson-Essentials-of-Pediatrics-7E2015.pdf

15. Tyson J, Kennedy K (2005): Trophic feedings for parenterally fed infants. Cochrane Database Syst Rev., 3: 504-509.

16. Bombell S, McGuire W (2009): Early trophic feeding for very low birth weight infants. Cochrane Database Syst Rev., 3: 4-8.

17. Tang B, Chi Z, Chen Y et al. (2020): Safety, Efficacy, and Biomarker Analysis of Toripalimab in Previously Treated Advanced Melanoma: Results of the POLARIS-01 Multicenter Phase II Trial. Clin Cancer Res., 26 (16): 4250-4259.

18. Ruan J, Zhou Y, Zhou M et al. (2019): Jasmonic Acid Signaling Pathway in Plants. Int J Mol Sci., 20 (10): 2479-83.

19. Corvaglia L, Fantini M, Aceti A et al. (2014): Predictors of full enteral feeding achievement in very low birth weight infants. PLoS One, 9(3): e92235. 